\title{
SISTEM PENDUKUNG KEPUTUSAN PEMILIHAN MENU MAKANAN TERBAIK BAGI PENDERITA GASTROESOPHAGEAL REFLUX DISEASE DENGAN METODE TOPSIS
}

\author{
Muhamad Ibrohim ${ }^{1}$, Maya Selvia Lauryn ${ }^{2}$, Rodhiyalloh Salma Nadziroh ${ }^{3}$ \\ ${ }^{1,2,3}$ Program Studi Teknik Informatika Fakultas Teknologi Informasi Universitas Serang Raya \\ Jln.Raya Cilegon Serang-Drangong Kota Serang
}

1b41m.cyber@gmail.com

\begin{abstract}
Abstrak - Mengetahui makanan apa saja yang baik bagi penderita GERD dapat membantu menunjang kesehatan mereka. Baik itu sebagai acuan dalam pemilihan makanan penyembuhan, pencegahan maupun sebagai terapi non medikamentosa. Namun terkadang penderita GERD masih sering kebingungan memilah-milih makanan bagi mereka dikarenakan banyaknya kriteria makanan yang harus sesuai dengan kondisi tubuh mereka. Sehingga seringkali mereka salah memilih makanan untuk menjaga kesehatan mereka. Oleh karena itu diperlukan sebuah sistem website yang tepat yang dapat memberikan informasi dan rekomendasi dengan menggunakan metode yang tepat, seperti Sistem Pendukung Keputusan Pemilihan Menu Makanan Terbaik Bagi Penderita GERD dengan Metode TOPSIS
\end{abstract}

Kata Kunci : GERD, Makanan Terbaik, TOPSIS

\section{PENDAHULUAN}

Penyakit Gastroesophageal Reflux Disease (GERD) kurang umum dijumpai dan derajat keparahan endoskopiknya lebih ringan di Asia dibandingkan di negara-negara Barat. Namun, data saat ini menunjukkan bahwa telah terjadi peningkatan frekuensi penyakit tersebut di Asia (M. Begawan, 2011).

Perbedaan etnis dan tata letak geografi merupakan faktor penting dalam mempelajari frekuensi penyakit, karena mungkin hal-hal tersebut menyoroti lingkungan atau pengaruh genetik dalam etiologi.

Kami kembali melakukan penelitian dari yang sudah di publikasikan mengenai epidemiologi yang berhubungan dengan GERD di Asia, berdasarkan definisi GERD, ilmu penelitian, tahun publikasi dan letak geografis. Dari penelitian berdasarkan populasi, pemerataan gejala yang mengacu pada GERD di Asia Timur ditemukan mencapai angka antara 2.5\% - $4.8 \%$ sebelum tahun 2005 dan $5.2 \%$ - 8.5\% dari rentang tahun 2005 sampai 2010. Di Tenggara dan Asia Barat angka yang didapat adalah $6.3 \%$ - 18.3\% setelah tahun 2005, dimana angka ini jauh lebih besar jika dibandingkan dengan Asia Timur. Ditemukan ada data epidemiologi yang kuat mengenai endoscopic reflux esophagitis dalam medical check-up para partisipan. Pemerataan endoskopik dari reflux esophagitis di Asia Timur meningkat dari 3.4\% - 5.0\% sebeluh tahun 2000, menjadi $4.3 \%$ - $15.7 \%$ setelah tahun 2005. Meski pun penelitian yang ada terbatas, namun pemerataan dari extraesophageal syndromes di Asia berada jauh diatas angka GERD yang seharusnya. Pemerataan dari esophagus milik Barrett adalah $0.06 \%-0.84 \%$ dari hasil health check-up para partisipan, yang dimana angka $0.31 \%-2.00 \%$ berasal dari Rumah sakit rekanan.

Berdasarkan Genval Workshop pada bulan Oktober 1997, Beberapa dokter menyatakan "Definisi dari pasien GERD adalah semua individu yang terpapar risiko komplikasi fisik akibat refluks gastroesofageal, atau mereka yang 
mengalami gangguan nyata terkait dengan kesehatan akibat gejala-gejala yang terkait dengan refluks. Namun bukan tidak mungkin penyakit ini dapat diobati atau mengurangi gejala yang timbul yakni melalui terapi non medikamentosa dengan melakukan perubahan gaya hidup yang salah satunya adalah perubahan pola makan. Makan adalah salah satu kebutuhan manusia untuk bertahan hidup. Manusia membutuhkan makanan untuk bertahan hidup, berkembang, dan memelihara kesehatannya semaksimal mungkin. Akan tetapi manusia terkadang lupa memperhatikan komposisi nutrisi yang terkandung dalam makanan yang di konsumsi. Bagi penderita GERD, memakan makanan yang baik adalah hal yang penting diperhatikan guna mendukung perbaikan fungsi pencernaan yang bermasalah. Hal ini juga berguna untuk membantu mengurangi kelebihan berat badan yang mana kegemukan atau obesitas adalah salah satu penyebab dari penyakit ini. Melihat kurang terkontrolnya pola makan, kurangnya informasi kandungan makanan yang baik atau tidak bagi penderita GERD juga kesulitannya memilih menu makanan yang sesuai kebutuhan jika ditinjau dari tingkat kandungan lemak, tingkat kandungan karbohidrat, tingkat kandungan protein, tingkat kandungan vitamin, tingkat sifat alkali dan juga berdasarkan cara pengolahan yang baik.

\section{METODOLOGI PENELITIAN}

Tahap awal penlitian dilakukan dengan cara peninjauan langsung ke lokasi penenelitian dan mengkaji terhadap masalah yang ditemui dengan melakukan interview atau wawancara serta mengadakan tanya jawab secara langsung mengenai permasalahan yang berkaitan dengan penyakit Gastroesophageal Reflux Disease (GERD), kemudian data yang terkumpul akan dianalisis dengan berfokus pada fungsi sistem informasi. Selanjutnya akan dibuat rancang bangun sistem pendukung keputusan makanan terbaik bagi penderita GERD dengan metode TOPSIS.

\section{A. Kebutuhan TOPSIS}

1. Data Alternatif

Data alternative adalah sebagai objek yang akan dinilai untuk mencari solusi dalam menghadapi masalah yang sedang dihadapi.

2. Data Kriteria

Data kriteria sebagai menjadi dasar penilaian untuk membandingkan tiap data alternative untuk pengambilan nilai keputusan. Kriteria bisa berupa cost atau benefit. Benefit berarti semakin besar nilainya semakin bagus, sebaliknya cost semakin kecil nilainya semakin bagus.

3. Bobot Keputusan
Bobot keputusan merupakan salah satu hal penting untuk menentukan solusi. Bobot berisi nilai tingkat kepentingannya menurut pengambil keputusan. Bobot dalam variabel linguistik, dapat dinilai dengan, sangat rendah, rendah, sedang, tinggi, sangat tinggi, dan sebagainya

\section{B. Tahapan TOPSIS}

Adapun langkah-ᄀlangkah algoritma dari TOPSIS ini adalah sebagai berikut (Indira, 2012) :

1. Rangking Tiap Alternatif

TOPSIS membutuhkan ranking kinerja setiap alternatif Ai pada setiap kriteria $\mathrm{Cj}$ yang ternormalisasi yaitu :

$$
r_{i j}=\frac{x_{i j}}{\sqrt{\sum_{i-1}^{m} x_{i j}^{2}}}
$$

Gambar 3.1 Rumus TOPSIS Tahap 1

Dengan $i=1,2, \ldots \ldots \ldots$; dan $j=1,2 \ldots \ldots \ldots$;

2. Matriks keputusan ternormalisasi terbobot

$$
y_{i j}=w_{i} r_{i j}
$$

Gambar 2.2 Rumus TOPSIS Tahap 2

Dengan $i=1,2, \ldots \ldots . . m$; dan $j=1,2 \ldots \ldots \ldots . n$;

3. Menentukan matriks solusi ideal positif \& matriks solusi ideal negatif

Menentukan matriks solusi ideal Positif Dan Negatif Solusi ideal positif $\mathrm{A}+$ dan solusi ideal negatif Adapat ditentukan berdasarkan ranking bobot ternormalisasi (yij) sebagai berikut :

$$
\begin{aligned}
& A^{+}=\left(y_{1}^{+}, y_{2}^{+}, \ldots, y_{n}^{+}\right) \\
& A^{-}=\left(y_{1}^{-}, y_{2}^{-}, \ldots, y_{n}^{-}\right)
\end{aligned}
$$

Gambar 3.3 Rumus TOPSIS Tahap 3

4. Menentukan jarak dengan solusi ideal positif \& matriks solusi ideal negatif Jarak antara alternatif Ai dengan solusi ideal positif dirumuskan sebagai berikut :

$$
D_{i}^{+}=\sqrt{\sum_{j=1}^{n}\left(y_{i}^{+}-y_{i j}\right)^{2}} .
$$

Gambar 3.4 Rumus TOPSIS Tahap 4.1 
Jarak antara alternatif Ai dengan solusi ideal negatif dirumuskan sebagai berikut :

$$
D_{i}^{-}=\sqrt{\sum_{j=1}^{n}\left(y_{i j}-y_{i}^{-}\right)^{2}}
$$

Gambar 3.5 Rumus TOPSIS Tahap 4.2

5. Nilai preverensi untuk setiap alternatif

Nilai preferensi untuk setiap alternatif Vi diberikan sebagai berikut :

$$
V_{i}=\frac{D_{i}^{-}}{D_{i}^{-}+D_{i}^{+}}
$$

Gambar 3.6 Rumus TOPSIS Tahap 5

Nilai Vi yang lebih besar menunjukan bahwa alternative Ai lebih dipilih atau hasil yang terbaik.

\section{HASIL DAN PEMBAHASAN}

Para penderita GERD saat ini kebanyakan melakukan pencegahan biasanya dengan cara bertanya kepada sesama penderita GERD yang lebih mengerti tentang menu makanan apa saja yang baik bagi mereka, banyak juga dari mereka yang mencari tahu makanan apa saja yang baik bagi mereka dengan cara browsing lewat internet. Untuk itu, perlu dibangun suatu sistem pendukung keputusan pemilihan menu makanan terbaik bagi penderita GERD dengan metode TOPSIS yang nantinya diharapkan dapat membantu para para penderita GERD dalam menghadapi penyakitnya.

\section{A. Data Alternative}

Tabel 1

Alternative dan Menu Makanan

\begin{tabular}{|l|l|l|}
\hline ID & \multicolumn{1}{|c|}{ Nama Menu } & \multicolumn{1}{|c|}{ Kategori } \\
\hline 1 & Coklat & Makanan \\
\hline 2 & Jus Bayam & Minuman \\
\hline 3 & Jus Buah Naga & Minuman \\
\hline 4 & Kerang & Makanan \\
\hline 5 & Sayur Bayam & Makanan \\
\hline
\end{tabular}

B. Data Kriteria

Tabel 2

Daftar Kriteria

\begin{tabular}{|c|c|l|l|c|}
\hline ID & Kode & Nama Kriteria & Atribut & Bobot Kriteria \\
\hline 1 & C1 & Lemak & Benefit & 1 \\
\hline 2 & C2 & Karbohidrat & Benefit & 2 \\
\hline
\end{tabular}

\begin{tabular}{|l|l|l|l|l|}
\hline 3 & C3 & Protein & Benefit & 3 \\
\hline 4 & C4 & Vitamin & Benefit & 5 \\
\hline 5 & C5 & Alkali & Benefit & 4 \\
\hline 6 & C6 & Pengolahan & Benefit & 4 \\
\hline
\end{tabular}

C. Data Pembobotan Keputusan

Tabel 3

\begin{tabular}{|c|c|c|c|c|c|c|c|}
\hline No & $\begin{array}{l}\text { Nama } \\
\text { Menu }\end{array}$ & $\mathrm{C} 1$ & $\mathrm{C} 2$ & C3 & $\mathrm{C} 4$ & C5 & C6 \\
\hline 1 & Coklat & $\begin{array}{l}\text { Sangat } \\
\text { Tinggi }\end{array}$ & $\begin{array}{l}\text { Sangat } \\
\text { Tinggi }\end{array}$ & Cukup & $\begin{array}{l}\text { Sangat } \\
\text { Rendah }\end{array}$ & $\begin{array}{l}\text { Sangat } \\
\text { Rendah }\end{array}$ & $\begin{array}{l}\text { Sangat } \\
\text { Tidak } \\
\text { Tepat }\end{array}$ \\
\hline 2 & $\begin{array}{l}\text { Jus } \\
\text { Bayam }\end{array}$ & $\begin{array}{l}\text { Sangat } \\
\text { Rendah }\end{array}$ & $\begin{array}{l}\text { Sangat } \\
\text { Rendah }\end{array}$ & Tinggi & $\begin{array}{l}\text { Sangat } \\
\text { Tinggi }\end{array}$ & $\begin{array}{l}\text { Sangat } \\
\text { Tinggi }\end{array}$ & $\begin{array}{l}\text { Sangat } \\
\text { Tepat }\end{array}$ \\
\hline 3 & $\begin{array}{l}\text { Jus Buah } \\
\text { Naga }\end{array}$ & $\begin{array}{l}\text { Sangat } \\
\text { Rendah }\end{array}$ & Tinggi & Rendah & $\begin{array}{l}\text { Sangat } \\
\text { Tinggi }\end{array}$ & $\begin{array}{l}\text { Sangat } \\
\text { Tinggi }\end{array}$ & $\begin{array}{l}\text { Sangat } \\
\text { Tepat }\end{array}$ \\
\hline 4 & Kerang & Cukup & Cukup & $\begin{array}{l}\text { Sangat } \\
\text { Tinggi }\end{array}$ & $\begin{array}{l}\text { Sangat } \\
\text { Rendah }\end{array}$ & $\begin{array}{l}\text { Sangat } \\
\text { Rendah }\end{array}$ & $\begin{array}{l}\text { Sangat } \\
\text { Tidak } \\
\text { Tepat }\end{array}$ \\
\hline 5 & $\begin{array}{l}\text { Sayur } \\
\text { Bayam }\end{array}$ & $\begin{array}{l}\text { Sangat } \\
\text { Rendah }\end{array}$ & $\begin{array}{l}\text { Sangat } \\
\text { Rendah }\end{array}$ & Tinggi & Tinggi & $\begin{array}{l}\text { Sangat } \\
\text { Rendah }\end{array}$ & $\begin{array}{l}\text { Sangat } \\
\text { Tidak } \\
\text { Tepat }\end{array}$ \\
\hline
\end{tabular}

Daftar Pembobotan Himpunan Kriteria

D. Perhitungan Data

Sebelum memulai perhitungan siapkan terlebih dahulu tabel matriks klasifikasi.

Tabel 4

Matrik Klasifikasi

\begin{tabular}{|l|c|c|c|c|c|c|}
\hline \multirow{2}{*}{ Alternatif } & \multicolumn{7}{|c|}{ Kriteria } \\
\cline { 2 - 7 } & Lemak & Karbohidrat & Protein & Vitamin & Alkali & Pengolahan \\
\hline Nama & $\mathrm{C} 1$ & $\mathrm{C} 2$ & $\mathrm{C} 3$ & $\mathrm{C} 4$ & $\mathrm{C} 5$ & C6 \\
\hline Coklat & 1 & 1 & 3 & 1 & 1 & 1 \\
\hline Jus Bayam & 5 & 5 & 4 & 5 & 5 & 5 \\
\hline Jus Naga & 5 & 2 & 2 & 5 & 5 & 5 \\
\hline Kerang & 3 & 3 & 5 & 1 & 1 & 1 \\
\hline Sayur Bayam & 5 & 5 & 3 & 4 & 1 & 1 \\
\hline & Benefit & Benefit & Benefit & Benefit & Benefit & Benefit \\
\cline { 2 - 7 }
\end{tabular}

1. Tahap 1

Langkah pertama yaitu membuat Rangking Tiap Alternatif. TOPSIS membutuhkan ranking penilaian setiap alternatif $\mathrm{Ai}$ pada setiap kriteria $\mathrm{Cj}$ yang ternormalisasi yaitu :

$$
r_{i j}=\frac{x_{i j}}{\sqrt{\sum_{i-1}^{m} x_{i j}^{2}}}
$$

Gambar 6.1 Rumus TOPSIS Tahap 1 
Dengan $i=1,2, \ldots \ldots . . m$; dan $j=1,2 \ldots \ldots \ldots . n$;

Tabel 5

Rangking Tiap Alternatif

\begin{tabular}{|l|c|c|c|c|c|c|}
\hline \multirow{2}{*}{ Alternatif } & \multicolumn{6}{|c|}{ Kriteria } \\
\cline { 2 - 7 } & Lemak & Karbohidrat & Protein & Vitamin & Alkal & Pengolahan \\
\hline \multicolumn{1}{c|}{ Nama } & C1 & C2 & C3 & C4 & C5 & C6 \\
\hline Coklat & 0,108 & 0,125 & 0,378 & 0,121 & 0,137 & 0,137 \\
\hline Jus Bayam & 0,542 & 0,625 & 0,504 & 0,606 & 0,687 & 0,687 \\
\hline Jus Naga & 0,542 & 0,250 & 0,252 & 0,606 & 0,687 & 0,687 \\
\hline Kerang & 0,325 & 0,375 & 0,630 & 0,121 & 0,137 & 0,137 \\
\hline Sqyyr Bayam & 0,542 & 0,625 & 0,378 & 0,485 & 0,137 & 0,137 \\
\hline
\end{tabular}

Langkah kedua yaitu membuat Matriks keputusan ternormalisasi terbobot

$$
y_{i j}=w_{i} r_{i j}
$$

Gambar 6.2 Rumus TOPSIS Tahap 2

Tabel 6

Matriks Keputusan Ternormalisasi Terbobot

\begin{tabular}{|l|c|c|c|c|c|c|}
\hline \multirow{2}{*}{ Alternatif } & \multicolumn{6}{|c|}{ Kriteria } \\
\cline { 2 - 7 } & Lemak & \multicolumn{6}{|c|}{ Karbohidrat } & Protein & Vitamir & Alkali & Pengolahan \\
\hline \multicolumn{1}{c|}{ Nama } & $\mathrm{C} 1$ & $\mathrm{C} 2$ & $\mathrm{C} 3$ & $\mathrm{C} 4$ & $\mathrm{C} 5$ & $\mathrm{C} 6$ \\
\hline Coklat & 0,108 & 0,25 & 1,134 & 0,606 & 0,549 & 0,549 \\
\hline Jus Bayam & 0,542 & 1,25 & 1,512 & 3,03 & 2,747 & 2,747 \\
\hline Jus Naga & 0,542 & 0,5 & 0,756 & 3,03 & 2,747 & 2,747 \\
\hline Kerang & 0,325 & 0,75 & 1,89 & 0,606 & 0,549 & 0,549 \\
\hline Sayur Bayam & 0,542 & 1,25 & 1,134 & 2,425 & 0,549 & 0,549 \\
\hline
\end{tabular}

3. Tahap 3

Langkah ketiga yaitu menentukan matriks solusi ideal

Positif Dan Negatif. Solusi ideal positif A+ dan solusi ideal negatif A- dapat ditentukan berdasarkan ranking bobot ternormalisasi (yij) sebagai berikut :

$$
\begin{aligned}
& A^{+}=\left(y_{1}^{+}, y_{2}^{+}, \ldots, y_{n}^{+}\right) \\
& A^{-}=\left(y_{1}^{-}, y_{2}^{-}, \ldots, y_{n}^{-}\right)
\end{aligned}
$$

Gambar 6.3 Rumus TOPSIS Tahap 3

Tabel 7

Matriks Solusi Ideal Positif

\begin{tabular}{|c|c|c|c|c|c|}
\hline \multicolumn{7}{|c|}{ Kriteria } \\
\hline Lemak & Karbohidrat & Protein & Vitamin & Alkali & Pengolahan \\
\hline. & & & $\ldots$ &. & \\
\hline 0,542 & 1,25 & 1,89 & 3,03 & 2,747 & 2,747 \\
\hline
\end{tabular}

\begin{tabular}{|c|c|c|c|c|c|}
\hline \multicolumn{6}{|c|}{ Kriteria } \\
\hline Lemak & Karbohidrat & Protein & Vitamin & Alkali & Pengolahan \\
\hline$\therefore$ & & $\therefore$ & $\therefore$ & $\therefore$ & $\therefore$ \\
\hline 0,108 & 0,25 & 0,756 & 0,606 & 0,549 & 0,549 \\
\hline
\end{tabular}

Tabel 8

Matriks Solusi Ideal Negatif
4. Tahap 4

Langkah keempat yaitu menentukan jarak dengan solusi ideal positif \& matriks solusi ideal negatif. Jarak antara alternatif $\mathrm{Ai}$ dengan solusi ideal positif dirumuskan sebagai berikut :

$$
D_{i}^{+}=\sqrt{\sum_{j=1}^{n}\left(y_{i}^{+}-y_{i j}\right)^{2}} .
$$

Gambar 6.4 Rumus TOPSIS Tahap 4.1

\begin{tabular}{|l|c|}
\hline $\begin{array}{l}\text { Tabell 9ematmiks Jarak Solusi Ideal } \\
\text { Nama }\end{array}$ & Positif \\
\hline Coklat & 0,083 \\
\hline Jus Bayam & 0,917 \\
\hline Jus Naga & 0,745 \\
\hline Kerang & 0,240 \\
\hline Sayur Bayam & 0,398 \\
\hline
\end{tabular}

Jarak antara alternatif Ai dengan solusi ideal negatif dirumuskan sebagai berikut:

$$
D_{i}^{-}=\sqrt{\sum_{j=1}^{n}\left(y_{i j}-y_{i}^{-}\right)^{2}}
$$

Gambar 6.5 Rumus TOPSIS Tahap 4.2

Tabel 10 Matriks Jarak Solusi Ideal Negatif

\begin{tabular}{|l|c|}
\hline \multicolumn{1}{|c|}{ Alternatif } & \multirow{2}{*}{$D_{\bar{i}}^{-}$} \\
\cline { 1 - 1 } Nama & \\
\cline { 1 - 1 } Coklat & 0,378 \\
\hline Jus B ayam & 4,160 \\
\hline Jus Naga & 3,974 \\
\hline Kerang & 1,258 \\
\hline Sayur B ayam & 2,154 \\
\hline
\end{tabular}

5. Tahap 5

Langkah kelima yaitu membentuk Nilai preferensi untuk setiap alternatif Vi diberikan sebagai berikut:

$$
V_{i}=\frac{D_{i}^{-}}{D_{i}^{-}+D_{i}^{+}}
$$

Gambar 6.6 Rumus TOPSIS Tahap 5

Tabel 11 Matriks Nilai Preferensi

\begin{tabular}{|l|c|}
\hline \multicolumn{1}{|c|}{ Alternatif } & \multirow{2}{*}{ 2, } \\
\cline { 1 - 1 } Nama & 4,160 \\
\hline Coklat & 0,378 \\
\hline Jus Bayam & 1,36 \\
\hline Jus Naga & 3,980 \\
\hline Kerang & 3,256 \\
\hline Sayur Bayam & \\
\hline
\end{tabular}




\section{E. Perancangan}

Pada tahap ini, model perancangan sistem yang digunakan adalah Unified Modeling Language (UML) salah satunya adalah diagram Use Case, memperlihatkan hubunganhubungan yang terjadi antara aktor dengan use case dalam sistem. Salah satu manfaat dari diagram use case adalah untuk komunikasi. Pada diagram use case, terlihat ada dua aktor yang terlibat di dalam sistem, yaitu admin dan user

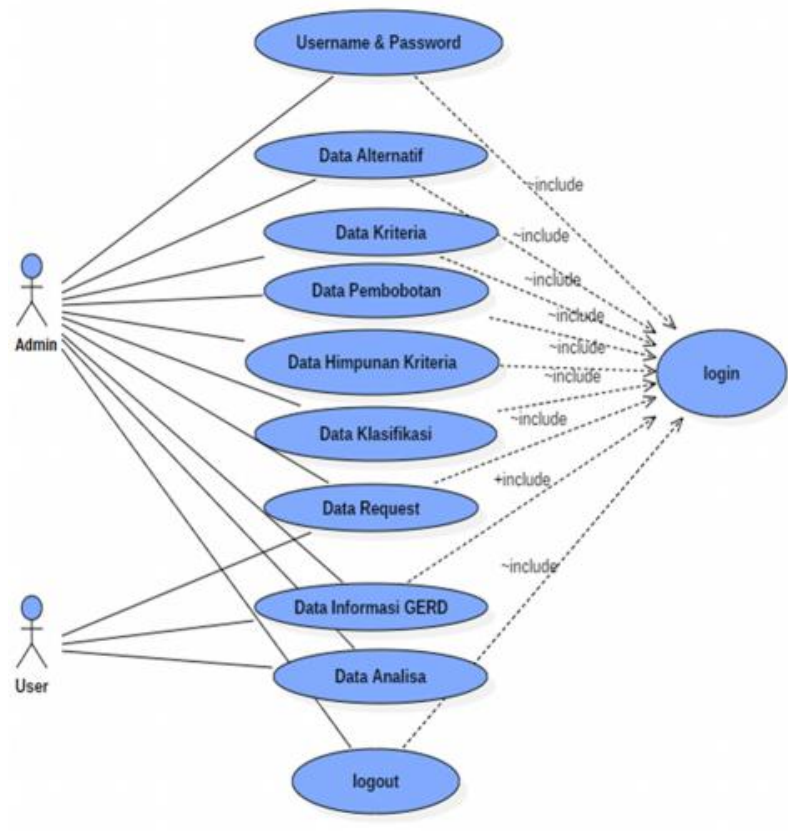

Gambar 1. Diagram Use Case

\section{F. Tampilan dan Fungsi}

Hasil dan pembahasan terhadap sistem yang dibangun dan dirancang dimulai dengan masuk ke menu Halaman Index berikut akan disampaikan mengenai tampilan dan penjelasan penggunaan Sistem Pendukung Keputusan Pemilihan Menu Makanan Terbaik Bagi Penderita GERD dengan Metode TOPSIS

1. Halaman Index

Adalah halaman pertama yang di tampilkan oleh sistem ketika user pertama kali memasuki sistem. Halaman ini mendeskripsikan apa saja fitur yang tersedia pada sistem. Pada halaman ini terdapat logo dari sistem dan nama sistem pada bagian navbar kanan. Untuk navbar kiri, terdapat menu berupa Home dan Fitur Kami.

Selanjutnya pada bagian content dihalaman ini, terdapat gambar background seorang dokter, yang disampingnya terdapat nama sistem, slogan dan juga button untuk mulai memasuki halaman user.

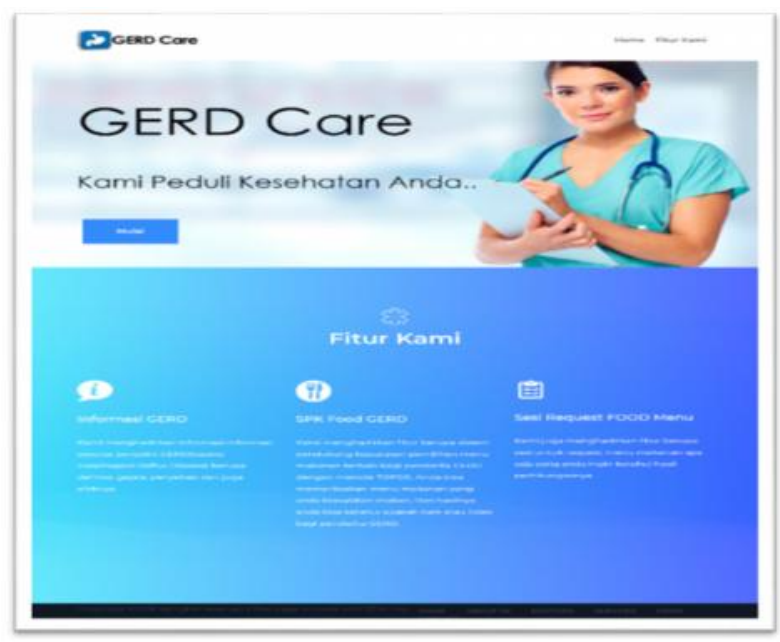

Gambar 2. Tampilan Halaman Index

\section{Tampilan Halaman Login}

Halaman login adalah halaman yang di tampilkan oleh sistem saat admin akan melakukan proses login yaitu dengan cara mengisi username beserta password sebagai hak akses untuk masuk kedalam sistem. Lalu di halaman ini juga terdapat button login untuk memasuki halaman admin.

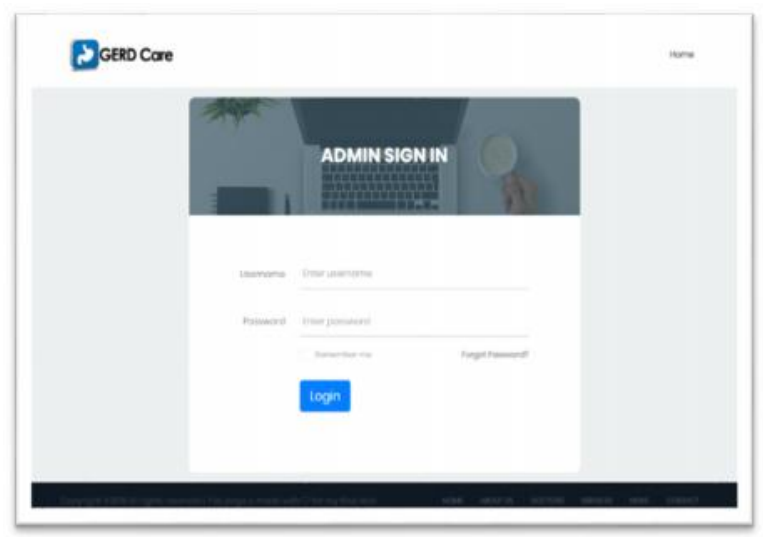

Gambar 3. Tampilan Halaman Dashboard

\section{Tampilan Halaman Dashboard}

Halaman dashboard adalah halaman yang di tampilkan pertama kali ditampilkan saat admin telah melakukan proses login dan berhasil masuk kedalam halaman admin. Halaman dashboard menampilkan logo, nama dan penjelasan sistem.

Bagian navbar terdapat logo dan nama sistem pada bagian kiri. Dan navbar bagian kanan terdapat foto dan juga username admin. Foto dan username admin ini disesuaikan berdasarkan username admin yang masuk ke halaman admin. 
Pada bagian samping terdapat sidebar untuk memilih menu-menu yang tersedia pada halaman admin. Menu yang tersedia pada halaman admin di antaranya adalah menu Dashboard, menu Informasi GERD, menu Data Admin, menu Data Request dan juga menu SPK Food GERD. Pada Menu SPK Food GERD terdapat sub-menu Master Data 1 dan Master Data 2. Pada menu Master Data 1 terdapat sub-menu Data Alternatif Makanan, Data Kriteria dan Data Pembobotan. Lalu pada menu Master Data 2 terdapat sub-menu Data Himpunan dan Data Klasifikasi.

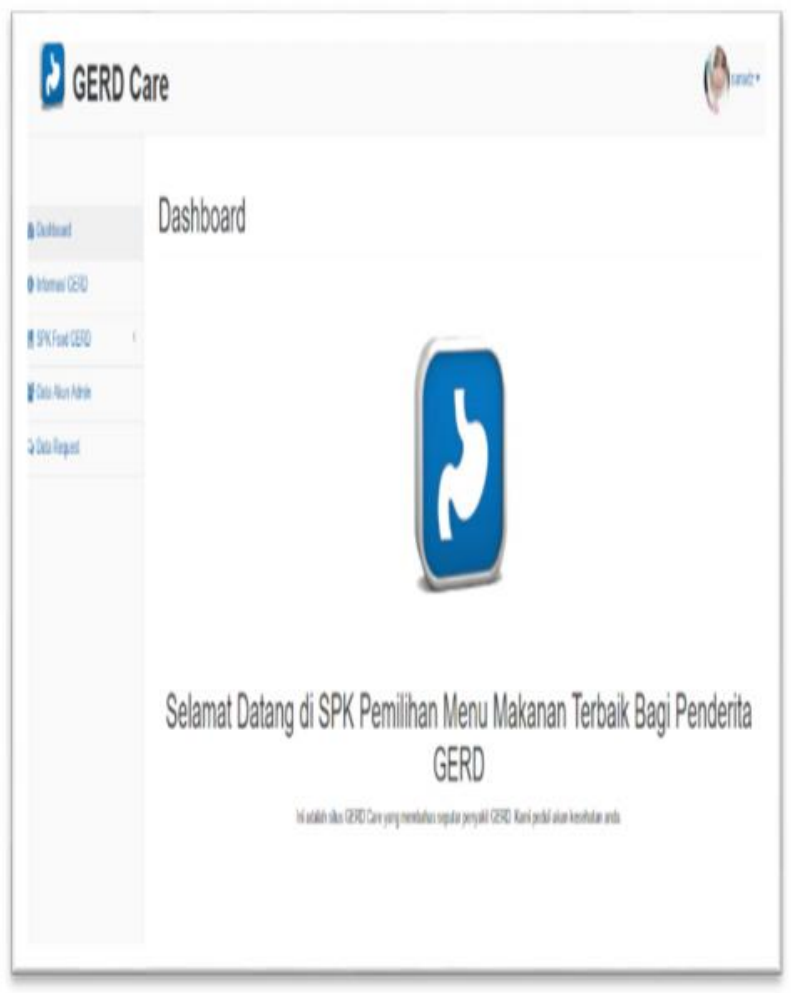

Gambar 4. Tampilan Halaman Dashboard

4. Tampilan Halaman Sistem Penunjang Keputusan (SPK) Makanan GERD

Halaman SPK makanan GERD adalah halaman yang bisa di akses oleh user untuk melihat hasil Analisa perhitungan dari tiap alternatif yang telah dinputkan oleh admin.

Pada halaman ini terdapat rincian perhitungan makanan dengan metode TOPSIS, lalu juga terdapat penjelasan dari mana data-data tersebut berasal dan dijelaskan pula mengapa kriteria-kriteria tersebut menjadi acuan dasar perhitungan.

Lalu pada bagian selanjutnya terdapat informasi untuk mengarahkan user ke halaman Request apabila user tidak menemukan perhitungan menu makanan yang di inginkan.

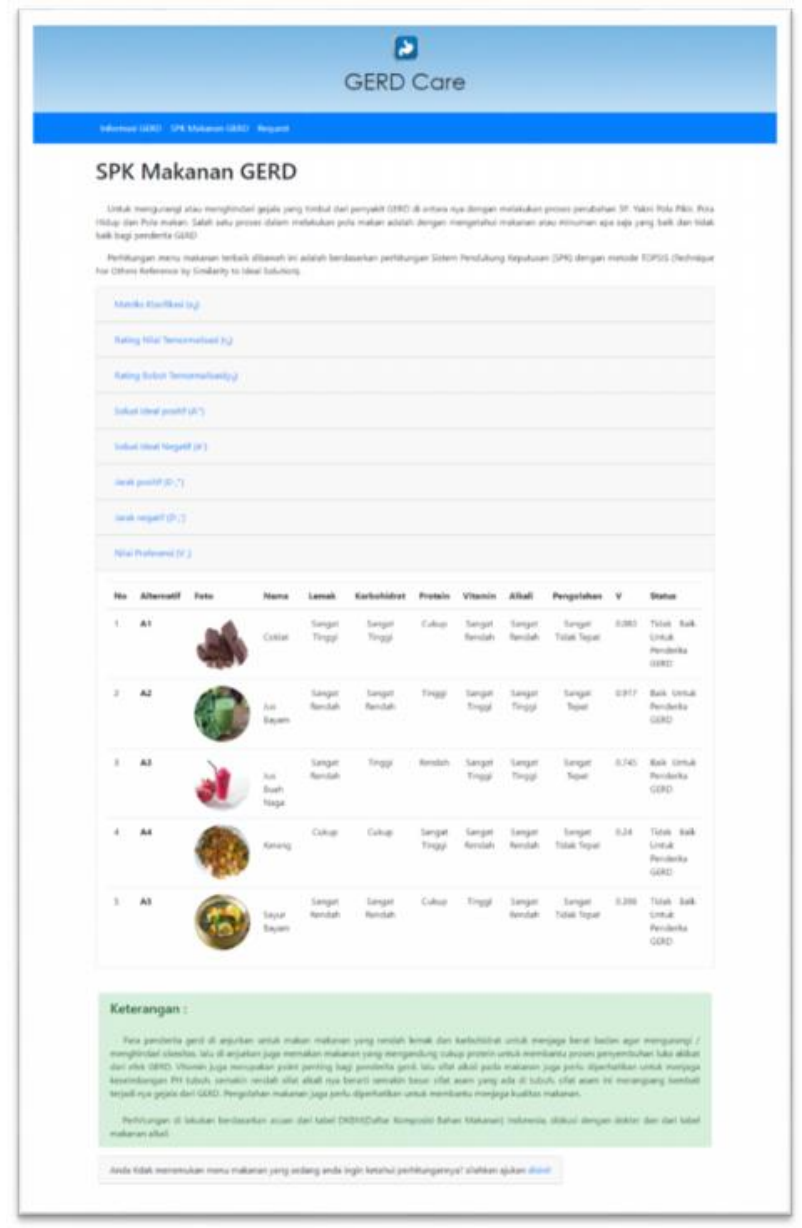

Gambar 5. Tampilan Halaman SPK Makanan GERD

\section{KESIMPULAN}

Berdasarkan hasil penelitian yang telah dilakukan dalam pembuatan aplikasi Sistem Pendukung Keputusan Pemilihan Menu Makanan Terbaik Bagi Penderita GERD dengan Metode TOPSIS maka dapat ditarik kesimpulan sebagai berikut:

1. Aplikasi Sistem Pendukung Keputusan Pemilihan Menu Makanan Terbaik Bagi Penderita GERD berbasis web ini berhasil menerapkan Metode TOPSIS sebagai metode perhitungannya dengan cara menentukan alternatif, bobot serta kriteria yang telah ditentukan. Adapun kriteria yang digunakan antara lain Lemak, Karbohidrat, Protein, Vitamin, Alkali dan juga Pengolahan. Dan sistem ini dapat membantu memberikan informasi dan saran guna memudahkan penderita GERD dalam mengambil keputusan terhadap pemilihan makanan terbaik untuk 
menunjang kesehatan mereka dengan hasil perankingan makanan terbaik.

2. Hasil uji berhasil mendapatkan alternatif menu makanan yang terbaik dan juga tepat untuk para penderita GERD dengan cara perhitungan sistem yang menghasilkan keluaran berupa rangking. Dimana hasil akhir penelitian ini adalah sebuah alternatif yang memiliki nilai tertinggilah yang menjadi alternatif terbaik.

3. Hasil akhir dari analisa perhitungan dengan metode TOPSIS yang diterapkan pada sistem yaitu didapat jenis menu Jus Bayam merupakan alternatif terbaik dari alternatif yang lain dengan nilai preferensi tertinggi dengan nilai 0,917 . Sedangkan menu Coklat merupakan alternatif terburuk dari alternatif yang lain dengan nilai preferensi terendah dengan nilai 0,083 .

\section{REFERENSI}

[1] Bestari, M.B. (2011). Penatalaksanaan Gastroesophageal Reflux Disease (GERD).

[2] Booklet Komunitas GERD Anxiety Indonesia. (2018). Jakarta: Sembuh dari GERD dan Axiety Dengan Melakukan Perubahan Gaya Hidup 3P : Pola Makan, Pola Hidup, Pola Berfikir.

[3] Brahmantyo, H.V dan Ariyanto Yudi. (2016). Sistem Pendukung Keputusan Penentuan Tanaman Obat Sesuai Jenis Penyakit Menggunakan Metode TOPSIS.

[4] Hermayudi, dan Ariani, A.P. (2017). Alergi Imunologi Klinik dan Gastroenterolgi. Yogyakarta: Muha Medika.

[5] Marsono, Boy, A.F., dan Dari Wulan. (2015). Sistem Pendukung Keputusan Pemilihan Menu Makanan pada Penderita Obesitas dengan menggunakan Metode Topsis.

[7] Salsabella, Amira. (2016). Sistem Pendukung Keputusan Penentuan Resep Masakan Berdasarkan Ketersediaan Bahan Makanan Menggunakan Metode Simple Additive Weighting (SAW) Berbasis Web.

[8] Suparno, H.A.O., Lantang, O.A., dan Lumenta Arie S.M (2016). Sistem Pendukung Keputusan Pemilihan Menu Bagi Penderita Hipertensi.

[9] Switrayni, N.W., Ainul, Q., dan Irwansyah.( 2016). Penentuan Susu Formula Ideal untuk Bayi Menggunakan AHP di Wilayah Kota Mataram. 